\title{
EKOLOGI BIMBINGAN KARAKTER ISLAMI RAMAH ANAK DI TK KHAS DAARUT TAUHIID BANDUNG
}

\author{
Farida Ulyani \\ Sekolah Tinggi Agama Islam Negeri Kudus \\ faridaulyani@yahoo.co.id
}

\section{ABSTRAK}

Berbagai kebobrokan moral dan kekerasan terhadap anak yang terjadi akhir-akhir ini menuntut strategi terobosan dari bimbingan karakter yang ramah anak. Riset ini membahas profil ideal ekologi bimbingan karakter Islami yang ramah anak di TK Khas Daarut Tauhiid Bandung. Penelitian ini menggunakan metode studi kasus karena keunikannya. Pengumpulan data menggunakan metode observasi, wawancara dan studi dokumentasi. Hasil penelitian adalaha bahwa kondisi lingkungan sekolah tersebut cukup mengakomodasi dalam mengembangkan nilai-nilai moral yang meliputi: akhlak kepada Allah Swt, Rasulullah Saw, sesama manusia dan lingkungan. Penguatan ekologi Islami dilakukan dengan pengkondisian pada struktur ruang fisik dan sosial. Sementara para guru melakukan pengauatan tiga struktur yang saling terkait yaitu: (a) Struktur peluang; diwujudkan dalam bentuk perangkat tugas, jenis dan berbagai bentuk kegiatan yang selaras dengan kebutuhan anak; (b) Struktur pendukung; 
perangkat sumber (resources) dan pengkondisian konteks yang sejalan dengan nilai-nilai karakter Islami;

(c) Struktur penghargaan sesuai psikologi anak.

Kata Kunci: Disabilitas, Ekologi, bimbingan karakter Islami, ramah anak

\section{ABSTRACT}

Various moral depravity and violence against children happened lately demanded breakthrough strategy of a character guidance child-friendly. This research discusses the ideal ecological profile for Islamic character guidance in friendly child in TK Khas Daarut Taubiid Bandung. This study uses a case study method because of its uniqueness. In collecting data using the method of observation, interviews and documentation methods. The results are: the ecological condition of TK Khas Daarut Taubiid has accommodated for Islamic character development at least in four aspect: character to Allah, the Prophet, human and environmental relations. In Strengthening of Islamic ecology done by conditioning the physical space and social structure. Meanwhile the teacher made three interconnected structures conditioning, namely: (a) The structure of opportunities; embodied in the form of tasks, kinds and various forms of activities that are consistent with the needs of the child; (b) a supporting structure; device resources and conditioning context in line with the values of the Islamic character; (c) Structure of the award appropriate child psychology.

Keywords: Ecology, guidance for Islamic character, child friendly

\section{A. Pendahuluan}

Akhir-akhir ini pendidikan nasional di Indonesia sedang menjadi sorotan berbagai pihak. Terutama setelah terjadi berbagai kejadian kekerasan dan pelecehan seksual yang melibatkan sebagian guru di beberapa sekolah berbagai kota besar. Bahkan kekerasan terhadap anak juga terjadi di sekolah berkelas baik dalam wujud 
kekerasan fisik, psikis maupun kekerasan verbal. Tentu masih segar dalam ingatan kasus kekerasan seksual di sebuah Taman Kanakkanan (TK) di salah satu sekolah internasional yang melibatkan guru dan tenaga kependidikan di Jakarta.

Kekerasan fisik mungkin dampaknya begitu jelas dan segera bisa ditangani secara medis, namun pada kekerasan psikis dan kekerasan verbal pada anak dampaknya lebih panjang dan bisa menyebabkan anak kehilangan harga diri dan rasa percaya diri, sehingga efek dominonya adalah terjadi krisisi moral (Faridy, 2015; Farida, 2011)

Menurut Kartadinata keterpurukan moral anak-anak bangsa tersebut juga tak lepas dari terjadinya simplifikasi arah dan tujuan pendidikan yang menimbulkan ketimpangan pencapaian tujuan individual dengan tujuan kolektif dan tujuan eksistensial (Kartadinata, 2009a). Terutama pada Pendidikan Anak Usia Dini (PAUD) yang belum mendapatkan perhatian lebih serius oleh banyak pihak.

Pendidikan karakter adalah sebuah proses yang berkesinambungan dan tak pernah berakhir (never ending process) selama sebuah bangsa ingin tetap eksis, karena itu harus menjadi bagian terpadu dari pendidikan alih generasi seiring dengan perkembangan manusia itu sendiri (Kartadinata, 2010), mulai dari anak ketika masih dalam kandungan, taraf usia dini hingga akhir hayatnya.

Pendidikan Anak Usia Dini (PAUD) memegang posisi yang paling fundamental karena dapat memberikan pengaruh yang "membekas" untuk dapat dijadikan sebagai landasan dasar pada usia selanjutnya. Dilihat dari sisi perkembangan otak manusia, anak usia dini merupakan usia sensitif karena itu menempati posisi vital dalam perkembangan jaringan otak manusia. Sally GanthamMcGregor sebagaimana dikutip oleh Sudjarwo (2008) menyebutkan pada rentang usia 0-6 tahun perkembangan otak manusia mengalami perkembangan yang paling tinggi terutama pada pendengaran dan 
pengliatan, bahasa dan juga fungsi kognitifnya.

Menurut Rahman (2002: 5) perkembangan otak anak usia 0-8 tahun sudah meliputi $80 \%$ dari perkembangan otak manusia secara keseluruhan. Hal ini dapat diperinci bahwa ketika bayi lahir perkembangan otak sudah mencapai $25 \%$ orang dewasa. Pencapaian perkembangan otak hingga $50 \%$ dilalui hingga berumur 4 tahun, untuk sampai $80 \%$ dilalui hingga berusia 8 tahun dan selebihnya berproses hingga usia 18 tahun.

Usia 0-6 tahun sebagai rentang waktu pendidikan usia dini sering disebut sebagai "usia emas" (golden age) karena pada usia tersebut perkembangan otak mereka mengalami perkembangan yang luar biasa. PAUD merupakan investasi besar bagi keluarga dan juga bangsa terutama dalam perannya turut memberikan landasan bagi penguatan karakter sejak dini (Suyanto, 2005: 1; Kurnanto, 2006: 1-2).

Paling tidak ada dua hal yang perlu diperhatikan pada pendidikan anak usia dini, yakni: 1) materi pendidikan, dan 2) metode pendidikan yang dipakai. Secara singkat dapat dikatakan bahwa materi maupun metodologi pendidikan yang dipakai dalam rangka pendidikan anak usia dini harus benar-benar memperhatikan tingkat perkembangan mereka. Memperhatikan tingkat perkembangan berarti pula mempertimbangkan tugas perkembangan mereka, karena setiap periode perkembangan juga mengemban tugas perkembangan tertentu (Harizal, 2008).

Perlu diperhatikan pula bahwa perkembangan manusia sebagai suatu proses yang berkelanjutan selalu melibatkan interaksi antara struktur biologis seorang individu dan lingkungannya, artinya isi, arah, kecepatan, dan hasil perkembangan individu merupakan produk interaksi yang kompleks antara "nature" dan "nurture" (Smith et al, 1975; Tarsidi, 2008; Ateel, tt). Dengan demikian perkembangan intelektual, emosional, sosial, sensoris, dan fisik bukan sematamata akibat struktur biologis yang defektif, melainkan merupakan produk interaksi antara karakteristik struktur biologis dengan 
variabel lingkungan. Intervensi untuk membantu perkembangan karakter anak seyogyanya tidak diarahkan hanya kepada anak itu saja melainkan juga kepada lingkungannya, baik lingkungan fisik maupun lingkungan sosialnya sehingga iklim pembelajaran menekankan pada kebermaknaan dan mampu membangkitkan daya kritis dan kreatif anak (Kauchak \& Eggen, 2007: 348-348).

Muhaimin (2009: 305-314) menegaskan dalam upaya penguatan karakter Islami, maka proses pendidikan yang di dalamnya menyangkut bimbingan menuntut adanya budaya agama (religiusitas) di sekolah. Dalam kontek adanya intervensi bimbingan karakter anak dengan pendekatan ekologis menjadi sebuah keniscayaan karena sebuah budaya sekolah yang religius hanya bisa dibangun dari sebuah lingkungan yang religius yang berproses secara kontinyu.

Pendekatan ekologis dibangun dari asumsi dasar ekologi perkembangan manusia, yakni menciptakan lingkungan yang memberi kesempatan dan kemudahan bagi individu untuk belajar dan berkembang sebagai manusia. Ekologi perkembangan adalah lingkungan belajar, yakni suatu wahana untuk mendeskripsikan, menjelaskan, meramalkan dan mengendalikan interaksi dan transaksi dinamis antara individu (anak didik) dengan lingkungan dan segala perlengkapan yang harus dipelihara (Kartadinata, 2009: 8).

Berangkat dari kesadaran akan pentingnya pengembangan karakter dalam pendidikan Islam serta relavansinya dengan pendekatan ekologis sebagai alternatif dalam membangun budaya sekolah yang Islami, maka diyakini bahwa perpaduan kedua variabel tersebut diasumsikan akan mampu mengembangkan karakter Islami peserta didik terutama untuk anak usia dini.

Perkembangan individu merupakan produk interaksi yang kompleks antara potensi diri yang dimiliki sejak lahir (nature) juga variabel lingkungan yang begitu kompleks (nurture). Pengembangan karakter Islami (akhlak) anak dibutuhkan bimbingan yang tidak hanya diarahkan kepada anak itu saja melainkan juga kepada 
lingkungannya, baik lingkungan fisik maupun lingkungan sosialnya. Karena itu yang menjadi fokus masalah pada penelitian ini terkait model bimbingan ekologi yang ramah anak untuk mendukung pengembangan karakter islami di PAUD dengan mengambil studi kasus di TK Khas Daarut Tauhiid. Melalui fokus masalah tersebut akan diurai dua hal; pertama kondisi lingkungan dalam mendukung pengembangan karakter Islami anak usia dini di TK Khas Daarut Tauhiid, dan kedua upaya guru dalam membantu pengembangan karakter Islami anak usia dini dengan melalui bimbingan ramah anak di TK tersebut.

Penelitian diharapkan mampu memberikan alternatif pendekatan terhadap bimbingan pengembangan karakter Islami dengan menyadari pentingnya ruang budaya (lingkungan) dalam upaya membangun karakter (feeling and acting the good) bagi anak menuju pembelajaran yang mendidik dan memberikan alternatif pemikiran dan pengalaman terbaik dalam bimbingan pengembangan karakter Islami bagi anak usia dini yang ramah anak.

Penelitian ini dilakukan dengan menggunakan pendekatan studi kasus dengan pertimbangan penelitian ini ingin memahami secara lebih mendalam suatu fenomena khusus atas suatu hal atau peristiwa yang unik dalam hal ini terkait pelaksanaan program bimbingan konseling dengan pendekatan ekologis untuk pengembangan karakter Islami bagi anak usia dini di TK Khas Daarut Taubiid. Dalam studi kasus penelitian akan menfokuskan penemuan (discovery), wawasan (insight) dan pemahaman (understanding) dalam suatu peristiwa/ kasus secara intensif, rinci dan mendalam. Dengan studi kasus inilah peneliti juga bisa memungkinkan melakukan penyelidikan suatu fenomena kontemporer termasuk dalam merespon isu bimbingan pengembangan karakter Islami dalam realitas konteksnya.

Proses pengumpulan data peneliti menggunakan tiga teknik yaitu; observasi, wawancara dan studi dokumentasi. Proses analisis data dilakukan dengan mengagregasi, mengorganisasi, dan mengklasifikasi data. Agregasi merupakan proses mengabstraksi hal- 
hal khusus menjadi hal-hal umum guna menemukan pola umum data. Data dapat diorganisasi secara kronologis, kategori atau dimasukkan ke dalam tipologi. Analisis data dilakukan sejak peneliti di lapangan, sewaktu pengumpulan data dan setelah semua data terkumpul atau setelah selesai dari lapangan.

\section{B. Pembahasan}

Keberadaan TK Khas Daarut Taubiid tak lepas dari sejarah panjang dakwah figur kunci KH. Abdullah Gymnastiar atau yang akrap disapa Aa Gym yang semula adalah aktivis masjid di Bandung. Bersama sahabat-sahabatnya yang memiliki visi sama setelah melihat keterpurukan moral di sekitar Geger Kalong, tempat dimana pesantren itu sekarang berdiri, maka pada 04 September 1990 berdirilah secara resmi Yayasan Daarut Taubiid (DT) yang mengembang pesantren Daarut Taubiid dan semangat entrepreneur santri.

Salah satu pola khas yang diterapkan adalah yang Manajemen Qalbu (MQ) sebagai brand image arah gerakannya yang hingga sekarang sudah memiliki unit pelatihan, penerbitan, radio dan televisi dakwah, minimarket, wisma penginapan, hingga Dompet Peduli Umat (DPU), juga lembaga pendidikan formal seperti Sekolah Menengah Kejuruan (SMK) dan Taman Kanak-Kanak (TK) khas yang semakin berkembang pesat.

(TK Khas Daarut Tauhid berdiri pada tanggal 17 Juli 2000 dan mendapatkan izin operasional dari Dinas Pendidikan Nasional (DIKNAS) pada tanggal 15 Desember 2000, dengan Nomor: 7052/102.11/DS/2000. TK yang beralamat di Jl Gegerkalong Girang No.55 j/ MIDC Bandung ini, lokasinya berada di kawasan pesantren, latar belakang pendiriannya adalah karena sebuah keinginan dari lembaga Daarut Taubid untuk turut bertanggung jawab secara moral atas kondisi pendidikan prasekolah di Indonesia, Terutama kondisi lingkungan di sekitar sekolah pada saat itu, sehingga harus ada upaya penyelamatan terhadap generasi masa depan. Upaya 
tersebut kemudian mewujud dalam pendirian sebuah pendidikan jenjang Taman Kanak-Kanak dengan konsep yang berbeda dari Taman Kanak-Kanak pada umumnya, yaitu dengan berbasiskan MQ sebagai ciri khas dari Daarut Taubid (Farida, 2011).

Awal mula berdirinya merupakan penggabungan dari sekolah Taman Pendidikan Al-Qur'an (TPA) dan Taman Kanak-Kanak AlQur'an (TKIT). TPA berdiri pada tahun 1993 yang menjadi kepala sekolah pertama kali adalah ibu Aryanti, kemudian digantikan oleh ibu Siti Sumarni, jadwal masuk sekolah ini dibagi menjadi dua shif yaitu jam 08.00-10.00 kemudian shif kedua jam 10.00-12.00. Pada tahun 1999 didirikanlah TKIT dengan Ibu Ekorini, S. Spi, sebagai kepala sekolahnya. TKIT didirikan sebagai upaya untuk membuat sekolah yang ideal dengan kurikulum standar nasional, karena dirasa keberadaan TPA selama ini lebih bersifat horizontal, kurang memenuhi standar ideal untuk sekolah pada tingkat usia dini.

Terdapat dua sekolah yaitu TPA dan TKA dalam satu tempat yang sama di pesantren Daarut Tauhiid, menyebabkan kedua sekolah ini harus bergantian gedung untuk kegiatan belajarnya. Hal ini sedikit banyak mempengaruhi kegiatan pembelajaran, sehingga tidak efektif. Akhirnya timbullah upaya untuk menggabungkan kedua sekolah tersebut.

TK tersebut tidak menekankan pada prestasi akademik semata (membaca, menulis dan berhitung) tetapi lebih menekankan pada pembentukan pribadi yang mempunyai kemampuan Manajemen Qolbu (MQ) yang siap menghadapi tantangan hidup dalam menghadapi ridha Allah Swt dengan visinya adalah: "Menjadikan Taman Kanak-Kanak unggulan untuk melahirkan generasi Tauhid yang memiliki karakter ahli Dzikir, Fikir dan Ikbtiar"

Dengan visi tersebut oleh para pengelolanya diharapkan menggapai beberapa tujuan antara lain:

1. Berkarakter baik, mencakup "Sembilan Pilar Karakter", yaitu: Cinta Allah dan Rasul-Nya; tanggung-jawab, kedisiplinan, 
kemandirian; kejujuran, amanah, arif; hormat dan santun; dermawan, suka menolong, gotong-royong; percaya diri, kreatif, pekerja keras; kepemimpinan dan keadilan; baik dan rendah hati; toleransi, kedamaian, dan kesatuan.

2. Membantu anak mengembangkan kecerdasan yang optimal dalam aspek kognitif, emosional, dan spiritual (multiple intelligence).

3. Membantu anak mencapai keseimbangan fungsional otak kiri dan otak kanan, yang dibingkai dengan nilai-nilai Ruhiyah.

4. Menguasai life skill: Kritis, mempunyai prinsip, berwawasan luas, problem solver, komunikator yang efektif, mudah beradaptasi, mampu menghadapi tantangan, berani mengambil resiko.

Untuk mendukung proses pembelaran yang selaras dengan karakter Islam, maka diupayakan suatu pendekatan yang relevan dengan sistem nilai yang diharapkan oleh sekolah. Berikut gambaran ekologi TK Khas Daaruut Tauhiid berikut pemanfaatannya dalam proses pendidikan dimana dimensi ekologi sebagai pendekata dalam bimbingan tersebut.

\section{Kondisi Lingkungan dalam Mengembangkan Karakter Islami Anak}

Kondisi lingkungan sangat menentukan proses pemebentukan karakter pada diri anak. Hal ini tak lepas dari perkembangan individu (anak) yang dalam interaksi sosialnya tidak lepas dari pengaruh lingkungan fisik, psikis maupun sosial. Sifat yang melekat pada lingkungan adalah perubahan, dan hal tersebut dapat mempengaruhi gaya hidup (life style) masyarakat (Yusuf \& Nurihsan, 2009: 117130; Irawan Sensus: 2010).

Keberadaan kondisi lingkungan yang ada di TK Khas Daarut Taubiid yang mendukung proses pengembangan karakter Islami, kalau dilihat dalam perspektif pendekatan ekologis yang disampaikan oleh Kartadinata yang menuntut tiga struktur lingkungan belajar yang perlu dikembangkan dalam satu keutuhan, yakni struktur 
peluang, dukungan, dan penghargaan. Maka penyiapan ekologi Islami menjadi suatu keniscayaan dalam proses pengembangan karakter Islami bagi peserta didik, khususnya anak usia dini.

\section{(1). Penyiapan Struktur Ekologi Islami}

Termasuk struktur peluang adalah mengkondisikan situasi, yang memungkinkan peserta didik mempelajari berbagai kecakapan hidup baik inter maupun antar pribadi, kecakapan menguasai dan mengendalikan pola respon. Sedangkan struktur dukungan, menyangkut perangkat sumber (resources) yang dapat diperoleh peserta didik dalam mengembangkan perilaku baru untuk merespon ragam stimulus (Kartadinata, 2009: 11).

Kondisi lingkungan TK Khas Daarut Taubiid yang termasuk dalam struktur peluang dan dukungan dalam mengembangkan karakter Islami antara lain berupa dalam wujud struktur ruang fisik berupa kedekatannya dengan masjid sebagai ruang budaya untuk penguatan spiritual.

Keberadaan ruang kelas yang seperti mengkondisikan kelas menjadi dinamis dan tidak menjenuhkan sehingga anak menjadi merasa betah dan belajar menyenangkan. Dinding ruang kelas yang dipenuhi dengan karya anak juga sebagai wujud apresiasi terhadap anak untuk selalu menghargai karya orang lain dan hal ini diwujudkan dengan memberikan kebebasan karyanya untuk ditempel di dinding.

Tampak pada pinggir ruangan kelas, berjajar secara rapi beberapa rak buku dan loker untuk menyimpan tas dan seluruh perlengkapan anak-anak sesuai dengan nama masingmasing. Inilah ruang pembiasaan disiplin yang riil dan dimulai dari hal yang sederhana, yakni dengan memanfaatkan ruang loker yang telah disediakan. Jadi ruang loker tidak bisa dilihat sekedar tempat menyimpan barang saja, tetapi sebagai media pendisiplinan diri agar berbuat adil dengan menempatkan barang-barangnya seperti tas, buku dan perlengkapan lain 
miliknya sesuai tempatnya masing-masing.

Keberadaan ruang musholla di TK Khas Daarut Taubiid dalam hal ini memiliki posisi yang penting dalam konteks sebagai ruang untuk memperkuat pembudayaan sekolah yang religius.

Di luar gedung TK Khas Daarut Taubiid yang masih termasuk lahan sekolah juga terdapat dua halaman yaitu halaman depan dan halaman belakang. Halaman sekolah sangat penting sebagai ruang untuk kegiatan pembelajaran yang sifatnya out door misalnya saat belajar pada sentra pasir, saat materi olah raga dan saat latihan menari. Pada saat menanti jam masuk sekolah biasanya anak-anak menunggu di halaman depan sambil bermain. Dengan demikian TK Khas Daarut Taubiid telah menyeimbangkan kebutuhan ruang olah rasa, olah pikir dan olah raga. Tiga komponen ruang tersebut menjadi sesuatu yang penting, terutama ruang olah raga sebagaimana tempat bermain bagi anak sebagai media pendidikan jasmani yang tepat.

Selain dukungan struktur ruang fisik, juga dipadu dengan dukungan struktur ruang sosial yaitu kondidi sosial yang religius dan sarat dengan nilai-nilai etis yang dilakukan dengan mengkonstruksi sistem pengetahuan 'baru' atau sehingga menjad "kuasa pengetahuan" sekaligus menjadi wacana etis yang harus diketahui, dirasakan dan dipraktekkan (Foucoult, 2005). Yang menarik kuasa pengetahuan baru etik-estetik tersebut diwujudkan dalam berbagai bentuk akronim slogan yang mudah dihafal dan dipraktekkan.

Beberapa slogan motivasi yang terkait etika maupun estetika khas Daarut Tauhid tersebut terpasang di beberapa lokasi strategis misalnya "TSP" (Tahan untuk tidak buang sampah sembarangan, Simpan sampah pada tempatnya, Pungut sampah Insyaallah sedekah); " 5 S" (Salam, Senyum, Sapa, Sopan, Santun); "3A" (Aku Aman Bagimu, Aku Menyenangkan Bagimu dan Aku Bermanfaat Bagimu), "BEBAS KOMIBA" (Berantakan Rapikan, Basah Keringkan, Kotor Bersihkan, Miring Luruskan, 
Bahaya amankan); "HHN" (Hadapi, Hayati, Nikmati).

Kondisi sosial sebagaimana terurai di atas menjadi struktur dukungan bagi TK Khas Daarut Taubiid yang berjalan sejak berdirinya hingga sekarang. Hal ini menjadi faktor pendukung bagi TK Khas Daarut Taubiid dalam mengembangkankan karakter Islami anak-anak karena sebagaimana ditegaskan oleh Muhaimin (2009) dan Kartadinata (2009), bahwa pembentukan karakter Islami menuntut adanya adanya budaya agama (religiusitas) di sekolah yang harus didukung dengan lingkungan fisik maupun lingkungan sosial. Budaya sekolah yang religius hanya bisa dibangun dari sebuah lingkungan yang religius yang berproses secara kontinyu.

(2). Upaya Guru dalam Mengembangkan Karakter Islami Anak

Pembahasan upaya guru dalam mengembangkan karakter Islami anak di TK Khas Daarut Taubiid ini diurai menggunakan sudut pandang pendekatan bimbingan ekologis sebagaimana dikemukakan oleh Kartadinata bahwa kerangka kerja pendekatan ekologis dalam bimbingan pengembangan karakter dibangun dari sebuah asumsi bahwa ekologi perkembangan manusia adalah lingkungan belajar. Karena itu hakekat proses bimbingan terletak pada keterkaitan antara lingkungan belajar dengan perkembangan individu, dan pembimbing (konselor) berperan sebagai fasilitator dan perekayasa lingkungan (environmental engineer)sebagai bagian dari mekanisme kuasa untuk mendisiplinkan individu agar memiliki kepatuhan dalam mengimplementasikan nilai-nilai moral yang diutamakan (Brewer, 2007: 13).

Dengan demikian untuk mencermati upaya guru dalam mengembangkan karakter islami anak di TK Khas Daarut Taubiid dapat dilihat dari bagaimana para guru dalam mengkondisikan lingkungan belajar yang yang terstruktur, mulai dari struktur peluang, struktur dukungan hingga struktur penghargaan sengaja untuk mengkondisikan peserta didik mengamalkan nilai-nilai 
moral berupa sembilan pilar karakter yang dikedepankan TK Khas Daarut Taubiid.

Beberapa karakter Islami atau akhlak yang dikembangkan oleh guru dengan upaya pengkondisian lingkungan yang ramah anak dengan beberapa cara sebagai berikut:

(a) Penguatan Akhlak kepada Allah Swt.

Beberapa hal yang dilakukan guru dalam mengenalkan kepada anak-anak terhadap Sang Pencipta salah satunya melalui pengenalan sifat-sifat Allah yang terangkai dalam Asmas'ul Husna>. Kegiatan ini dilakukan secara rutin diawal pembelajaran diucapkan anak-anak secara bersamasama di halaman sekolah. Dalam setiap lafaldz asmaul husna yang diucapkan, guru bersama-sama dengan anak didik memperagakan dengan anggota tubuh, misalnya 'Ya Rahman Ya Rahim' maka tangan menelungkup ke dada, 'Ya Qowiyyu' maka diperagakan dengan tangan mengepal. Adapun terkait dengan penguatan $u>$ budiyah misalnya dalam ritual menjalankan sholat yang benar dan penuh cinta, guru mengkondisikan struktur peluang anak untuk memahaminya dan mengamalkannya dengan bimbingan guru setiap hari dengan learning by doing, yakni melaksanakan sholat Dzuhur secara berjama'ah.

Dalam hal membimbing anak berpuasa di bulan Ramadhan, guru-guru di TK Khas Daarut Taubid mengajarkan kepada anak-anak dengan mengajak berlatih puasa sesuai kemampuannya. Pada waktu bulan Ramadlan di sekolah dari jam 08.00 pagi sampai pulang jam 11.00, anak-anak tidak diperkenankan membawa bekal makan dan minum. Selama 3 jam anak-anak diajarkan untuk mampu menahan lapar dan dahaga.

Dalam mengenalkan anak kepada ritual ibadah haji, guru memberikan materi praktik manasik haji. Malalui 
praktik manasik haji ini sekaligus memberikan peluang bagi anak untuk menjadikan ibadah haji sebagai salah satu impianya kelak ketika sudah dewasa. Kegiatan manasik haji ini adalah kegiatan rutin tahunan yang diadakan oleh TK Daarut Taubid setiap bulan Zlulhijiah.

Kegiatan lain yang memberi peluang anak-anak TK Khas Daarut Tauhiid dalam memupuk cinta kepada Allah adalah pembiasaan membaca al-Qur'an berdoa kepada Allah dalam kehidupan sehari-hari. Guru di TK Khas Daarut Tauhid selalu melatih anak untuk membiasakan berdo'a dalam setiap aktifitas yang dilakukan, mulai dari masuk sekolah maka pelajaran diawali dengan pembacaan do'a terlebih dahulu.

(b) Penguatan Akhlak kepada Rasulullah Saw.

TK Khas Daarut Tauhiid dalam rangka memperkuat struktut peluang untuk menumbuhkan rasa cinta kepada Rasulullah, Nabi Muhammad Saw antara lain dilakukan dengan dua metode yaitu:

(a) Melalui Nyanyian (lagu).

Lagu-lagu yang diajarkan oleh guru pembimbing untuk mengenalkan dan mencintai Rasulullah adalah menyanyikan lagu yang berjudul "Nabi Muhammad" dengan syairnya yaitu.

"Nabi kita semua, Muhammad itu namanya

Di Mekkah tempat lahirnya

Di Madinahlah pulangnya

Siti Aminah ibunya

Abdul Mutholib eyangnya

Siti Fatimah lah putrinya

Muhammad 3x

Shollahu 'alaa Muhammad

Shollahu 'alaihi Wassalam.”

(Dokumen Panduan TK Khas Daarut Tauhiid, 2011)

Lagu lain judulnya adalah "Muhammad" dengan 
syairnya sebagai berikut:

"Ibunya Aminah 2x

Ayahnya Abdullah 2x

Nama kakeknya kuingat juga

Abdul Muthalib menyayanginya

Muhammad Akhlaqul Karimah sifatnya."

(Dokumen Panduan TK Khas Daarut Tauhiid, 2011)

Lagu tersebut diajarkan/dinyanyikan sebagai selingan di tengah-tengah pelajaran ketika anak-anak sudah menampakkan kejenuhan. Pada awalnya guru memberikan contoh mendendangkan nyanyian tersebut, lalu anak menirukan. Begitu seterusnya sampai anakanak bisa menguasai lagu dan mampu menyanyikan bersama-sama (Farida, 2011).

(b) Melalui Tepuk (Tepuk Nabi);

Tepuk Nabi ini berupa nyanyian sederhana yang dikombinasikan dengan tiga tepukan lalu diirangi dengan pernyataan yang diurai secara sistematis sebagai berikut: Nabimu $* * * \quad$ Muhammad***

Ayahnya *** Abdullah ***

Ibunya *** Siti Aminah ***

Lahirnya *** Di Mekkah ***

Tanggalnya *** Dua Belas ***

Bulannya *** Rabiul Awal $* * *$

Tahunnya *** Tahun Gajah ***

Wafatnya $* * * \quad$ Madinah $* * *$

Putrinya $* * \quad$ Fatimah $* * *$

Pamannya *** Abu Tholib ***

Kakeknya*** Abdul Muthalib***

(Dokumen Panduan TK Khas Daarut Tauhiid, 2011)

Dalam studi mengenai manfaat lagu yang dinyanyikan sambil bertepuk tangan, menyimpulkan 
bahwa manfaat dari tepuk tangan akan sangat baik dalam melaitih gerakan otot dan syaraf anak-anak yang dilakukan dengan gembira dan riang. Aktivitas tepuk selanjutnya akan selalu mempengaruhi hormon kecerdasan di otak. Diungkapkan kegiatan tepuk tangan dapat melatih otak dan mempengaruhi perkembangan daerah otak yang lainnya (Purwanto, 2010). Dengan demikian 'Tepuk Nabi' tersebut menjadikan anak lebih mudah untuk mengingat hal-hal yang berkaitan dengan Nabi, karena anak tidak merasa sedang belajar tapi sedang bermain namun sarat dengan nilai cinta kepada Nabi. Untuk bisa mencintai, perlu menganali lebih dahulu. Tak kenal, maka tak sayang. Dengan mengenal maka, rasa sayang akan tumbuh.

(c) Akhlak kepada Sesama:

Pengkondisian struktur peluang dalam mengembangkan nilai toleransi di TK Khas Daarut Tauhiid antara lain disampaikan melalui nyanyian tentang adanya perbedaan baik negara maupun kebudayaan seperti syair yang sering dinyanyikan yaitu:

"Amerika , Australia

India Aca-aca,

China Gongxi Fa Chai,

Papua wuwuwuwuwu...."

(Saat mengakhiri lagu tersebut, anak-anak pun menepukkan tangan ke mulutnya menirukan sikap orang Papua).

Sementara untuk mengembangkan rasa kasih sayang antar umat Islam disampaikan melalui hafalan pendek ungkapan bijak dalam Bahasa Arab (Mahfudhah) tentang pentingnya toleransi yaitu "Al-muslimu Akbul Muslim” sesama muslim bersaudara. Nampak dalam 
menghafalkan Mahfudhoh ini anak-anak sudah sangat lancar, mengucapkannya pun dengan nada suara yang dikeraskan.

Ungkapan lain disampaikan oleh guru antara lain ungkapan hikmah; "Irham man duunaka" sayangilah orang lain, "Awin akhaka ma istatha'tum" tolonglah saudaramu semampumu, selain pembiasaan melalui ungkapan hikmah guru juga membiasakan anak-anak untuk berakhlak sebagaimana etika yang diajarkan dalam al-qur'an "Wabil wa>lidaini Ihsa>na". Berbuat baiklah kepada kedua orang tuamu. "walas taqul lahuma> "uffin" janganlah berkata "ah" kepada orang tuamu.

Apa yang disampaikan guru TK Khas Daarut Tauhiid kepada anak-anak sebagaimana di atas baik berupa lagu "Amerika-Australia..." maupun hafalan singkat sejumlah mahfudhah adalah bagian dari tahap untuk memahamkan nilai (moral knowing) atau realitas dengan cara yang sederhana. Hal ini selaras dengan tuntutan pendidikan karakter yang mensyaratkan aspek mengetahui (knowing), selain aspek rasa (moral feeling) dan melaksanakan (moral acting) (Muhaimin, 2009: 305-314; Lickona, 1991).

Maka ketika guru mengajarkan nyanyian tentang realitas perbedaan “Amerika, Australia..”, dan setelah anak-anak menyanyikan dengan meriah, maka gurupun membantu menghayatinya dan menghubungkan dengan Sang Pancipta (Kha>liq). Meskipun manusia itu hidup di berbagai tempat (Amerika, Australian, India hingga Papua) yang memiliki nyanyian dan tarian yang berbedabeda, mereka semua itu adalah bagian dari makhluk Allah yang perlu disayangi dan dicintai (Farida, 2011).

Pada saat guru memberikan penjelasan tambahan terkait materi isi nyanyian tersebut adalah bagian dari 
upaya menyentuh rasa dan kesadaran (moral feeling). Sedangkan pada tataran implementasinya membutuhkan habitus, yakni struktur pendukung yang diurai tersendiri pada bagian berikutnya.

Demikianjuga ketika gurumembantu menghafalkan sejumlah ayat-ayat yang memuat berbagai pesan kasih sayang sebagaimana tersebut diatas, menunjukkan bahwa guru memberi pengenalan (moral knowing) awal tentang pentingnya menebar kasih sayang kepada sesama manusia, kepada sesama muslim dan hormat kepada orang tua. Maka ketika guru mengajarkan hafalan "Wabil waslidaini Ihsa>na". Berbuat baiklah kepada kedua orang tuamu. "wala> taqul lahuma> "uffin"” janganlah berkata "ah" kepada orang tuamu; setelah itu guru juga memberi penjelasan mengapa harus berbuat baik kepada kedua orang tua. Maka guru mengajak untuk mengingat kedua orang tua, ibu yang telah mengandung dan melahirkan, kedua orang tua nya ayah dan ibu telah merawat sejak lahir dengan penuh kasih sayang. Tahap penjelasan guru tersebut adalah sebagai bagian untuk menyentuh rasa atas nilai-nilai moral yang terkandung dalam kata-kata mutiara atau hadits (moral feeling).

(d) Penguatan Akhlak kepada Lingkungan

Dalam mengupayakan cinta anak kepada alam lingkungan, guru TK Khas Daarut Tauhiid mengemasnaya dalam sebuah paket kegiatan camping. Salah satu bentuk cinta alam yang ajarkan oleh guru-guru pembimbing di sekolah TK Khas Daarut Tauhid adalah mengadakan kegiatan rutin tahunan yaitu camping yang diselenggarakan di kompleks pesantren, Acara camping ini mendidik anak untuk mandiri dan lebih dekat dengan lingkungan dalam suasana malam hari.

Kegiatan lain juga dilakukan dengan "berkebun 
bersama", yakni anak-anak diajak untuk menanam tanaman apotik hidup. Kegiatan berkebun tidak hanya di lakukan anak-anak TK Khas Daarut Tauhid di sekolahan saja, tetapi anak-anak juga diajak untuk berkebun secara langsung, anak-anak diajak memetik sayur di EcoPesantren, yaitu kawasan perkebunan di luar area sekolah TK tetapi masih dalam satu lingkup yayasan Daarut Tauhiid. Setelah sampai di lokasi anak-anak dikumpulkan di sebuah saung dekat perkebunan, kemudian ada pihak dari pengelola kebun yang memberikan penjelasan mengenai tanaman sayur yang mereka tanam dan bagaimana cara memetiknya. Setelah semua paham, maka anak-anak bersama ibu guru dan pihak pengelola menuju kebun untuk langsung memetik sayur. Sayuran yang sudah dipetik diperbolehkan untuk dibawa pulang. Mendengar hal ini anak-anakpun langsung antusias dan tersenyum gembira.

Sedangkan upaya guru dalam menumbuhkan rasa sayang anak terhadap binatang di TK Khas Daarut Tauhid antara lain dengan pemberian nama kelompok menggunakan nama binatang. Kelas yang berjumlah 21 anak, dalam kegiatan belajar setiap harinya dibagi menjadi 3 kelompok yaitu kelompok kucing. Guru pembimbing juga sering menceritakan kepada anak-anak supaya menyayangi binatang yang ada disekitar kita, dengan menceritakan bahwa Rasulullah juga menyayangi dan memelihara binatang kucing.

Pembelajaran lain yang dilakukan oleh guru pembimbing agar anak-anak menyayangi binatang yaitu dengan mengajak anak-anak dalam field trip ke Taman Kupu-Kupu atau kebun binatang. Kegiatan outing, pembelajaran luar kelas dengan pemilihan lokasi yang sejalan dengan tema pebelajaran yang sedang dipelajari 
anak. Kemudian hari berikutnya di sekolah anakanak diajak untuk menceritakan kembali, satu persatu anak-anak diberi kesempatan untuk menceritakan pengalamannya mengunjungi Taman Kupu-Kupu.

Apa yang dilakukan oleh para guru pembimbing di TK Khas Daarut Tauhiid dengan begitu dekatnya membawa anak kepada cinta alam (flora dan fauna) dengan mengupayakan struktur ekologis yang mendukung, maka dalam hal ini menurut H.A.R. Tilaar (1985) telah menempatkan bimbingan (pendidikan) diselenggarakan dalam dua proses: (1) proses hominisasi, yaitu memposisikan manusia sebagai makhluk hidup di dalam dunia atau ekologinya; (2) proses humanisasi, memposisikan manusia sebagai makhluk yang bermoral (akhlak). Sebagai makhluk bermoral, manusia tak sekedar hidup, tetapi hidup untuk mewujudkan eksistensi sebagai manusia yang berbudaya berikut kesadaran religiusitas yang dimilikinya.

\section{(2). Pengkondisian Struktur Penghargaan (Reward)}

Dalam proses bimbingan yang terjadi di TK Khas Daarut Tauhiid, penghargaan adalah bagian yang tak terpisahkan dalam proses bimbingan tersebut. Penghargaan dalam bingkai bimbingan ekologis adalah bagian sistem struktur yang harus dipenuhinya yakni sebagai komponen struktur penghargaan (Kartadinata, 2009).

Dalam memberikan struktur penghargaan kepada anakanak, para guru selalu mendampingi dan memantau setiap anak selama camping dan berlatih berkebun. Penghargaan berupa ucapan-ucapan positif selalu keluar dari mulut guru seperti; "Subhanallah, hebat, pintar, berani, bagus", ketika menyaksikan anak-anak bisa membaur dan berani secara aktif terlibat di dalam proses berkebun maupun camping. (Ulyani, 2011;62). 
Sementara khusus pada saat kunjungan ke Eco-pesantren Setelah pihak pengelola memperbolehkan membawa pulang setiap sayur yang dipetiknya secara langsung. Hal ini memacu anak semakin semangat untuk memetiknya dan hal ini adalah juga bagian dari struktur penghargaan kepada anak yang sedang mengenal kebun sayur secara langsung dan benar-benar sungguhan. Karena itu hal ini menjadi pengalaman bagi anak dan secara tidak langsung anak juga merasa dihargai sebagai pribadi yang mampu berkebun meski masih kecil.

Struktur peghargaan yang dipraktekkan oleh TK Khas Daarut Taubiid dalam hal ini selaras dengan yang disampaikan oleh Ike R. Sugianto menyangkut perlunya memperhatikan penghargaan dalam beberapa hal; (1) Berikan penghargaan jika aktivitas anak positif agar menjadi stimulusnya; (2) Sesuaikan dengan perjuangan yang dilakukan anak, jangan berlebihan; (3) Berikan hadiah atau penghargaan dengan penuh ketulusan dan bukan basa basi; (4) Setiap memberi hadiah yang bersifat materiil barengi dengan hadiah sosial. (Sugianto, 2010).

\section{Simpulan}

Berdasarkan pembahasan di atas, dapat disimpulkan beberapa kesimpulan bahwa kondisi lingkungan TK Khas Daarut Taubiid sudah cukup mengakomodasi dalam mengembangkan empat pilar karakter Islami (akhlak), yaitu terkait dengan akhlak kepada Allah Swt, akhlak kepada Rasulullah Saw, akhlak kepada sesama manusia dan akhlak kepada lingkungan. Struktur kondisi lingkungan yang mendukung tersebut meliputi: (a) Segi pembagian struktur ruang di TK Khas Daarut Taubiid; (b) Kondisi lingkungan di sekitar TK Khas Daarut Taubid memiliki posisi strategis sebagai struktur pendukung dalam memperkuat pengembangan nilai-nilai karakter Islami; (c) Struktur ruang sosial yang terbentuk dalam proses panjang di Pesantren Daarut Taubiid yang menampakkan implementasi moral (moral acting) atas sistem pengetahuan etis dan estetis dalam 
memperkuat budaya religius di TK Khas Daarut Taubiid.

Upaya bimbingan yang dilakukan guru dalam pengembangan karakter Islami di TK Khas Daarut Taubiid menampakkan struktur ekologis yang kuat. Hal ini dapat dicermati melalui tiga struktur yang saling terkait: (a) Struktur peluang, yaitu diwujudkan dalam bentuk perangkat tugas, jenis dan berbagai bentuk kegiatan yang sesuai kebutuhan anak sehingga memungkinkan anak-anak mempelajari, menghayati dan menumbuhkan rasa senang terhadap nilai-nilai Islam; (b) Struktur pendukung, yaitu perangkat sumber (resources) dan pemanfaatan dukungan konteks yang sejalan dengan nilai-nilai karakter Islami; (c) Struktur penghargaan, yaitu pemberian balikan yang memperkuat struktur kognitif, sikap atau perilaku baru(moral knowing, moral feeling dan moral acting) yang selaras dengan sisten nilai karakter Islami.

Dengan demikian pengembangan akhlak pada anak tidak cukup hanya disampaikan dalam ruang kelas yang monoton, tetapi memerlukan dukungan ekologis yang saling terkait antara struktur peluang, dukungan dan sekaligus penghargaan secara sistemik dan terencana. Dengan proses seperti itu maka proses konstruksi dan reproduksi nilai-nilai etik dan estetik akan tertanam dalam peserta didik akan lebih mudah terjadi sebagaimana dalam kasus di TK Khas Daarut Taubiid Bandung. 


\section{DAFTAR PUSTAKA}

Abdullah, A. (2010). "Pendidikan Karakter: Mengasah Kepekaan Hati Nurani" Makalah disampaikan pada acara sarasehan Nasional Pendidikan Karakter, Direktorat Pendidikan Nasional, di Hotel Santika Yogyakarta, 15 April 2010.

Brewer, J.A. 2007. Introduction to Early Childhood Education; Preschool Through Primary Grade. Boston: Pearson.

Farida, U. 2011. "Bimbingan Dengan Pendekatan Ekologis Dalam Membantu Pengembangan Karakter Islami Anak Usia Dini (Studi di TK Khas Daarut Taubid Bandung)", Tesis, Prodi Bimbingan Konseling, Pascasarjana Universitas Pendidikan Indonesia (UPI), Bandung.

Faridy, F. 2015, "Kekerasan Verbal dan Dampaknya Terhadap Mental Anak Usia Dini” dalam, Jurnal Pendidikan Usia Dini Vol 9,Edisi 2 2015: ISSN 1693-1602

Foucault, M. 2007. Disiplin Tubuh, Bengkel Individu Modern. Yogyakarta: LkiS.

Kartadinata, S. 2009a. Kerangka Kerja Bimbingan dan Konseling dalam Pendidikan, Pendekatan Ekologis Sebagai Suatu Alternatif. Bandung: Universitas Pendidikan Indonesia.

Kartadinata, S. 2009b. Terapi dan Pemulihan Pendidikan. Bandung: Universitas Pendidikan Indonesia.

Kauchak, D. \& Eggen, P. 2007. Educational Psycology; Windows to Classroom. Seventh Edition. US \& Canada: Pearson Merill Prentice Hall.

Koesoema, Doni. A. 2007. Pendidikan Karakter, Strategi Mendidik

Anak di Zaman Global. Jakarta: PT. Gramedia Widiasarana Indonesia.

Lickona, T. 1991 Educating For Character, New York: Bantam Books. Lickona, T. (1992). “Educating For Character, How Our School Can 
Teach Respect and Responsibilit, New York: Bantam Books.

Lickona, T. 1993. "The Return of Character Education" dalam JOURNAL CITATION: Educational Leadership, v51 n3 p6-11 Nov 1993. [Online] Tersedia: http://www.hi-ho.ne.jp/ taku77/refer/lickona.htm (10 Juli 2010).

Lickona, T. 1994. "Raising Good Children: From Birth Though the Teenage Years, New York: Bantam Books.

Megawangi, R. 2001 Mengapa Pendidikan Karakter. Mimeograp, Indonesia Heritage Foundation. Tidak diterbitkan.

Megawangi, R. 2007 Pendidikan Karakter, Solusi yang Tepat untuk Membangun Bangsa (Cet. Kedua). Bogor: Indonesia Heritage Foundation

Muhaimin 2008. Paradigma pendidikan Islam, Upaya Mengefektifkan Pendidikan Agama Islam di Sekolah. Bandung: Remaja Rosda karya

Muhaimin 2009. Rekonstruksi Pendidikan Islam, Dari Paradigma Pengembangan, manajemen kelembagaan, kurikulum hingga strategi pembelajaran. Jakarta: Raja Grafindo Persada.

Rachman, B. M. 2001. Suara Hati dan Fitrah Manusia. Tersedia: http://islamlib.com/id/artikel/suara-hati-dan-fitrah-manusia (23 Juni 2011).

Rahman, H. S. 2002. Konsep Dasar Pendidikan Anak Usia Dini. Yogyakarta: PGTKI Press.

Rakhmat, J. 2007. Dabulukan Akblak daripada Fiqh. Bandung: Mizan

Rahmat, J. 2010. Membangun Karakter: Mengembalikan Jiwa Pedidikan. Makalah Pembekalan Guru SMU Plus Muthohhari Bandung.

Sauri, S. 2011. Filsafat dan Teosofat Akhlak, Kajian Filosofis dan Teosofis tentang Akblak, Karakter, Nilai, Moral, Etika, Budi Pekerti, Tata Krama dan Sopan Santun. Bandung: Rizqi Press 
Sensus, A.I. 2010. Pentingnya Layanan Bimbingan Dan Konseling Di Sekolah Inklusi. Tersedia: http://balerancage.wordpress. com/2010/12/13/ pentingnya-layanan-bimbingan-dankonseling-di-sekolah-inklusi/ (30 Maret 2010)

Setyoadi Purwanto. 2010. Tepuk Tangan Bikin Anak Pintar. Tersedia: http://kakadi.wordpress.com/2011/03/10/tepuk-tangan-bikinanak-pintar/ (20 Juni 2011)

Smith, R. M. \& Neisworth, J. T. \& Berlin, C. M. Jr. 1975. The Exceptional Child. New York: McGraw-Hill Book Company.

Suyanto, S. 2005. Dasar-Dasar Pendidikan Anak Usia Dini. Yogyakarta: Hikayat Publishing.

Syaodih, E \& Agustin, M (2008), Bimbingan Konseling untuk Anak Usia Dini, Jakarta: Universitas Terbuka.

Syaodih, E. 2005, Bimbingan di Taman Kanak-Kanak, Jakarta: Departemen Pendidikan Nasional, Dorektorat Pembinaan Tenaga Kependidikan dan Ketenagaan Perguruan Tinggi.

Syaodih, N. S (Eds.) 2003, Materi Bimbingan dan Konseling (untuk Pengembangan Diri, Sosial dan Karir), Bandung: Mutiara

Tarsidi, D. 2008. Intervensi bimbingan dan konseling untuk Membantu Perkembangan Kompetensi Sosial Anak Tunanetra. [Online] Tersedia: http://groups.yahoo.com/group/ditplb/ message/704 (10 Juli 2010)

Tim TK Daarut Tauhiid. 2010. Buku Panduan TK Khas Daarut Tauhiid.

UU No.20/2003 tentang Sistem Pendidikan Nasional (Sisdiknas).

Yusuf, S. 1998, Model Bimbingan dan Konseling dengan Pendekatan Ekologis, UPI Bandung: Disertasi Tidak diterbitkan

Yusuf, S \& Nurihsan, J. 2009, Landasan Bimbingan dan Konseling, Bandung: Remaja Rosdakarya

Yusuf, S. 2009, Psikologi Perkembangan Anak dan Remaja, Bandung: Remaja Rosdakarya 
Halaman ini bukan sengaja untuk dikosongkan 